Michael Tuval

\title{
From Jerusalem Priest to Roman Jew
}

On Josephus and the Paradigms of Ancient Judaism

[Vom Jerusalemer Priester zum römischen Juden. Über Josephus und Paradigmen des antiken Judentums.]

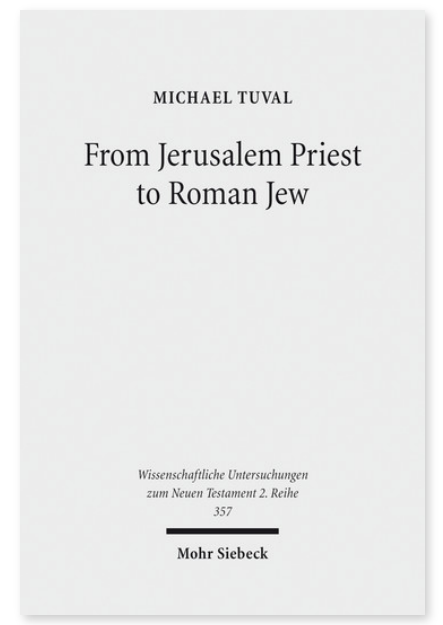

2013. X, 345 Seiten. WUNT II 357

ISBN 978-3-16-152495-0

DOI 10.1628/978-3-16-152495-0

eBook PDF 114,00€

ISBN 978-3-16-152386-1

fadengeheftete Broschur $114,00 €$
Veröffentlicht auf Englisch.

Michael Tuval liefert eine diachrone Untersuchung der Religion von Flavius Josephus. Weil die Diasporajuden nicht regelmäßig am religiösen Leben im Jerusalemer Tempel teilnehmen konnten, behauptet der Autor, dass sie andere Muster für die Ausübung der jüdischen Religiosität entwickelten. Er sieht Josephus als einen Juden, der seine Karriere als judäischer Priester begann, aber dann nach Rom zog und langsam zu einem Intellektuellen der Diaspora wurde. Josephus' erstes Werk, Geschichte des judäischen Krieges, zeigt das Judentum aus der Perspektive eines judäischen Priester, mit dem Tempel und dem Kult im Zentrum. Nachdem beide verloren gegangen sind, schwand die religiöse Hoffnung. Tuval analysiert auch Jüdische Altertümer, welches fünfzehn Jahre später geschrieben wurde. Das religiöse Bild hatte sich drastisch verändert: Der Tempel wurde durch das Gesetz an den Rand gedrängt oder ersetzt.

Michael Tuval Born 1971; 1998 BA; 2003 MA; 2012 PhD, Hebrew University of Jerusalem, Israel; has lectured for several years on Jewish history at the Hebrew University of Jerusalem; at present a postdoctoral researcher in Munich.
Jetzt bestellen:
https://mohrsiebeck.com/buch/from-jerusalem-priest-to-roman-jew-9783161524950?no_cache=1
order@mohrsiebeck.com
Telefon: +49 (0)7071-923-17
Telefax: +49 (0)7071-51104 